\title{
Milk production response to varying protein supply is independent of forage digestibility in dairy cows
}

\author{
L. Alstrup, ${ }^{* 1}$ M. R. Weisbjerg, ${ }^{*}$ L. Hymøller, ${ }^{*}$ M. K. Larsen, $†$ P. Lund, ${ }^{*}$ and M. O. Nielsen \\ *Department of Animal Science, and \\ †Department of Food Science, AU Foulum, Aarhus University, DK 8830 Tjele, Denmark \\ ‡Department of Veterinary Clinical and Animal Sciences, Faculty of Health and Medical Sciences, University of Copenhagen, DK 1870 \\ Frederiksberg C, Denmark
}

\begin{abstract}
The aim of this experiment was to examine whether the positive response in milk production to increased crude protein (CP) supply in dairy cows was dependent on the digestibility of the forage. Forty-eight lactating Danish Holstein cows were used in a $4 \times 4$ Latin square design experiment with 4 rations: (1) high digestibility and high $\mathrm{CP}$ concentration ( $\mathrm{HdHp}),(2)$ high digestibility and low $\mathrm{CP}$ concentration (HdLp), (3) low digestibility and high $\mathrm{CP}$ concentration ( $\mathrm{LdHp}$ ), and (4) low digestibility and low CP concentration (LdLp). All rations contained $30 \%$ corn silage, $25 \%$ grass-clover silage, and $45 \%$ concentrate on a dry matter (DM) basis. Different digestibilities were obtained by replacing a high-digestible grass-clover silage combined with a high-digestible corn silage with a low-digestible grassclover silage combined with a low-digestible corn silage. Organic matter digestibilities were 79.8 and $74.7 \%$ in the high- and low-digestibility rations, respectively. Dietary $\mathrm{CP}$ concentration in the ration was increased by substituting barley and sugar beet pulp with rapeseed meal and soybean meal, whereby $\mathrm{CP}$ increased from 13.9 to $14.0 \%$ (Lp) to 15.7 to $16.0 \%$ (Hp). All cows were offered $3 \mathrm{~kg}$ of the same concentrate per day in the automatic milking system in addition to the mixed ration. Every feeding period lasted 3 wk, and DM intake and milk yield were measured in the last week in each period, and milk samples for determining milk composition, including fatty acid content, and blood samples were taken during the last $3 \mathrm{~d}$ of each period. Dry matter intake increased by $2.2 \mathrm{~kg} / \mathrm{d}$ on $\mathrm{Hd}$ compared with $\mathrm{Ld}$ and by $0.7 \mathrm{~kg} / \mathrm{d}$ on $\mathrm{Hp}$ compared with Lp. The positive effect on DM intake was reflected in the energy-corrected milk (ECM) yield, as a higher ration digestibility increased the ECM yield by $1.7 \mathrm{~kg} / \mathrm{d}$ and a higher $\mathrm{CP}$ concentration increased it by $1.2 \mathrm{~kg} / \mathrm{d}$. We detected no interaction between forage digestibility
\end{abstract}

Received October 10, 2013.

Accepted April 2, 2014.

${ }^{1}$ Corresponding author: Lene.Alstrup@agrsci.dk and CP concentration on milk production. Reduced digestibility was accompanied by an increase in the plasma level of glucose, suggesting that other nutrients were limiting to milk production. In conclusion, milk production responses to dietary $\mathrm{CP}$ supply appeared independent of forage digestibility.

Key words: corn and grass clover silage, mammary nutrient supply and extraction, milk fatty acids

\section{INTRODUCTION}

Protein requirements of lactating dairy cows are high due to their need for AA for milk protein synthesis. In an environmental context, improving the efficiency of the conversion of dietary $\mathrm{CP}$ to milk protein is desirable, and this is mainly achieved by reducing the dietary CP supply (Nielsen et al., 2003) and consequently the $\mathrm{N}$ output in urine (Børsting et al., 2003). However, a considerable decrease in voluntary DMI by dairy cows is expected when dietary protein supply is limited (Fisher, 2002), because a protein-deficient diet can limit microbial activity in the rumen and impair digestion (Oldham, 1984). This will affect the DMI negatively and this negative effect has been found to increase progressively as protein supply decreases (Weisbjerg et al., 2010). A higher dietary protein concentration increases DMI, although responses vary according to the level of protein supplementation (Allen, 2000; M'hamed et al., 2001). This positive effect on DMI can be explained by a range of effects on digestibility in the rumen (Oldham, 1984). Nutrient intake and associated energy balance in the cow will affect nutrient composition in the blood and hence also the patterns of mammary nutrient supply (Safayi and Nielsen, 2013) and milk FA composition (Gross et al., 2011). Generally, older cows have a higher milk yield response to increased nutrient supply than do first-lactation cows (Smith et al., 1978; Bossen and Weisbjerg, 2009).

Increasing the concentration of protein in the ration to improve the productivity of cows results in lower utilization of nitrogen when $\mathrm{N}$ is consumed in excess of nutritional requirements (Walker et al., 2005). The 
process of transforming the excess protein into urea is energy-demanding.

Weisbjerg et al. (2010) compared recent studies where highly digestible forages were used with earlier experiments where lower digestible forages were used; they concluded that cows eating rations containing high-digestible forages were less sensitive to low protein concentration than cows eating rations containing low-digestible forages. The hypothesis of this study was therefore that feed intake and milk production would be less negatively affected by a reduction in CP supply when forage digestibility is high than when it is low.

The objective of this experiment was to study the interactive effect of $\mathrm{CP}$ supply and forage digestibility on dairy cow DMI, mammary nutrient uptake, ECM yield, and milk composition. Mammary nutrient uptake was assessed based on analyses of blood parameters, and milk composition was assessed based on analyses of total fat, protein, and lactose, as well as FA composition.

\section{MATERIALS AND METHODS}

\section{Cows, Experimental Design, Facilities, and Feeds}

The experiment was carried out at the Danish Cattle Research Centre (Foulum, Denmark) and complied with the guidelines set out by the Danish Ministry of Justice with respect to animal experimentation and the care of animals used for scientific purposes.

Forty-eight lactating Danish Holstein cows that had reached peak yield and would remain lactating throughout the experiment were used, and included 20 first-, 12 second-, 12 third-, and 4 fourth-lactation cows. At the beginning of the experiment, cows averaged $( \pm \mathrm{SD})$ $643 \pm 63 \mathrm{~kg}$ of BW, $33.9 \pm 7.6 \mathrm{~kg}$ of daily ECM yield, $21.3 \pm 4.4 \mathrm{~kg}$ of daily DMI, and $115 \pm 45$ DIM (range: 33 to 214 DIM).
Cows were blocked according to parity (first lactation and later) and DIM and randomly assigned to 1 of 4 dietary treatments in a replicated $4 \times 4$ Latin square design with a $2 \times 2$ factorial arrangement of treatments. Each experimental period lasted $21 \mathrm{~d}$.

The treatments were (1) high OM digestibility and high $\mathrm{CP}$ concentration (HdHp), (2) high OM digestibility and low CP concentration (HdLp), (3) low OM digestibility and high CP concentration ( $\mathbf{L H H p}$ ), and (4) low OM digestibility and low CP concentration (LdLp). All rations consisted of 30\% corn silage, $25 \%$ grass-clover silage, and $45 \%$ concentrate on DM basis. Differences in ration digestibilities were obtained by use of Ld or Hd silages (Table 1 and Table 2). Organic matter digestibilities were 74.7 and $79.8 \%$ in $\mathrm{Ld}$ and $\mathrm{Hd}$, respectively. Dietary CP was increased by substituting barley and sugar beet pulp with rapeseed meal and soybean meal to reach protein concentrations of 13.9 to 14.0\% CP for Lp and 15.7 to $16.0 \%$ CP for Hp (Table 3). Rations were adjusted using urea to reach similar $\mathrm{CP}$ concentrations (per $\mathrm{kg}$ of $\mathrm{DM}$ ) for the 2 different forage qualities.

Cows were kept in a loose-housing system with slatted floor and cubicles with mattresses. A cow-traffic system for free access to the automatic milking system (AMS; DeLaval AB, Tumba, Sweden) was used, and the AMS was equipped with a device for automatic measurement of milk yield and milk sampling. Cows in first lactation had a milking allowance if the interval from the last milking exceeded 6 or $10 \mathrm{~h}$ for cows $<21$ DIM or $\geq 21$ DIM, respectively, or if predicted milk yield per milking exceeded $9 \mathrm{~kg}$. Older cows had a milking allowance if the interval from the last milking exceeded 6 or $10 \mathrm{~h}$ for cows $<21$ DIM or $\geq 21$ DIM, respectively, or if predicted milk yield exceeded $10 \mathrm{~kg}$. The AMS also measured the amount of concentrate dispensed and weighed concentrate refusals at the end of each cow visit. A platform scale (Danvaegt, Hinnerup,

Table 1. Chemical composition ( $\mathrm{g} / \mathrm{kg}$ of DM unless otherwise noted) of feedstuffs including high-digestible (Hd) and low-digestible (Ld) silages

\begin{tabular}{|c|c|c|c|c|c|c|c|c|}
\hline Feedstuff & $\begin{array}{l}\mathrm{DM}, \mathrm{g} / \mathrm{kg} \text { of } \\
\text { fresh matter }\end{array}$ & $\mathrm{OM}$ & $\mathrm{CP}$ & $\begin{array}{l}\text { Crude } \\
\text { fat }\end{array}$ & NDF & Starch & $\begin{array}{l}\text { Energy, MJ } / \mathrm{kg} \\
\text { of DM }\end{array}$ & $\underset{\%}{\mathrm{OMD}}{ }^{1}$ \\
\hline Hd Grass-clover silage & 414 & 913 & 162 & 32.1 & 358 & - & 7.4 & 81.0 \\
\hline Ld Grass-clover silage & 464 & 912 & 148 & 28.7 & 500 & - & 5.3 & 66.2 \\
\hline Ld Corn silage & 235 & 967 & 101 & 17.3 & 509 & 134 & 6.2 & 72.0 \\
\hline Barley & 854 & 981 & 115 & 29.0 & 174 & 527 & 8.8 & 84.5 \\
\hline Beet pulp dried & 891 & 931 & 92 & 9.3 & 389 & - & 7.9 & 87.7 \\
\hline Urea, ${ }^{2} 80 \%$ & 980 & - & 2,300 & - & - & - & - & - \\
\hline Concentrate, $\mathrm{AMS}^{3}$ & 869 & 931 & 214 & 37.0 & 259 & - & 8.2 & 81.4 \\
\hline
\end{tabular}

${ }^{1} \mathrm{OMD}=$ estimated in vivo OM digestibility; calculated from measured in vitro digestibility according to Åkerlind et al. (2011).

${ }^{2}$ Comprising $80 \%$ urea, $11 \% \mathrm{NaSO}_{4}, 9 \% \mathrm{CaCO}_{3}$.

${ }^{3} \mathrm{AMS}=$ automatic milking system. 
Table 2. Quality of fermentation of high-digestible (Hd) and low-digestible (Ld) silages

\begin{tabular}{|c|c|c|c|c|c|c|c|}
\hline Feedstuff & $\mathrm{pH}$ & $\underset{\% \text { of } N}{\operatorname{Ammonia}} \mathrm{N}$, & $\begin{array}{l}\text { Lactic acid, } \\
\% \text { of DM }\end{array}$ & $\begin{array}{c}\text { Acetic acid, } \\
\% \text { of DM }\end{array}$ & $\begin{array}{c}\text { Propionic acid, } \\
\% \text { of DM }\end{array}$ & $\begin{array}{c}\text { Butyric acid, } \\
\% \text { of DM }\end{array}$ & $\begin{array}{l}\text { Ethanol, } \\
\text { \% of DM }\end{array}$ \\
\hline Hd Grass-clover silage & 4.4 & 6.2 & 4.6 & 1.0 & 0 & 0 & 0.02 \\
\hline Ld Grass-clover silage & 4.5 & 6.1 & 2.2 & 0.6 & 0.005 & 0 & 0.02 \\
\hline Ld Corn silage & 3.7 & 8.7 & 8.5 & 2.1 & 0 & 0.01 & 0.31 \\
\hline
\end{tabular}

Denmark) was installed below each AMS for automatic recording of cow live weight. For automatic recording of intake of mixed ration, the Insentec RIC system was used (Insentec, Marknesse, the Netherlands). Cows had free access to drinking water. For further details, see Bossen et al. (2009).

\section{Experimental Procedures}

Feed Composition. Fresh silage samples were taken every week for DM determination. Samples of concentrates were also taken weekly. The weekly samples were pooled for 6 -wk periods for chemical analysis, giving 2 pooled samples per feed for the whole experiment.

After drying $\left(60^{\circ} \mathrm{C}\right.$ for $\left.48 \mathrm{~h}\right)$, the feed samples were milled using a hammer mill through a 1-mm screen before chemical analysis. Pooled samples were analyzed for $\mathrm{DM}$ by drying at $60^{\circ} \mathrm{C}$ for $48 \mathrm{~h}$ and for ash by combustion at $525^{\circ} \mathrm{C}$ for $6 \mathrm{~h}$ (AOAC International, $2000)$. Crude protein was calculated as $6.25 \times$ total $\mathrm{N}$ measured by the Dumas principle, as described by Hansen (1989), using a Vario MAX CN (Elementar Analysesysteme GmbH, Hanau, Germany). Crude fat was measured by Soxhlet extraction with petroleum

Table 3. Ration ingredients and chemical composition of treatments

\begin{tabular}{|c|c|c|c|c|}
\hline \multirow[b]{2}{*}{ Item } & \multicolumn{4}{|c|}{ Treatment $^{1}$} \\
\hline & HdHp & HdLp & $\mathrm{LdHp}$ & LdLp \\
\hline \multicolumn{5}{|l|}{ Ingredient, $\mathrm{g} / \mathrm{kg}$ of DM unless noted } \\
\hline Hd Grass-clover silage & 240 & 240 & 0 & 0 \\
\hline Ld Grass-clover silage & 0 & 0 & 241 & 234 \\
\hline Hd Corn silage & 303 & 303 & 0 & 0 \\
\hline Ld Corn silage & 0 & 0 & 304 & 322 \\
\hline Barley & 95 & 123 & 95 & 120 \\
\hline Beet pulp dried & 113 & 140 & 113 & 137 \\
\hline Rapeseed meal & 87 & 52 & 87 & 51 \\
\hline Soybean meal & 19 & 0 & 19 & 0 \\
\hline Urea, $80 \%$ & 2.6 & 2.6 & 0 & 0 \\
\hline Vitamin and mineral mix $^{2}$ & 15 & 16 & 15 & 15 \\
\hline Concentrate (automatic milking system) & 126 & 124 & 126 & 121 \\
\hline \multicolumn{5}{|l|}{ Composition } \\
\hline $\mathrm{DM}, \mathrm{g} / \mathrm{kg}$ of fresh matter & 604 & 604 & 583 & 574 \\
\hline $\mathrm{OM}$ & 927 & 927 & 928 & 929 \\
\hline $\mathrm{CP}$ & 157 & 139 & 160 & 140 \\
\hline Crude fat & 29.3 & 28.0 & 25.5 & 24.0 \\
\hline \multicolumn{5}{|l|}{ FA } \\
\hline $\mathrm{C} 16$ & 3.80 & 3.80 & 3.58 & 3.56 \\
\hline Total C18 & 16.15 & 14.94 & 13.51 & 12.16 \\
\hline NDF & 317 & 320 & 393 & 399 \\
\hline Starch & 136 & 151 & 91 & 107 \\
\hline $\mathrm{AAT}_{20},{ }^{3} \mathrm{~g} / \mathrm{kg}$ of $\mathrm{DM}$ & 86.1 & 78.2 & 81.1 & 74.8 \\
\hline $\mathrm{PBV}_{20}, \mathrm{~g} / \mathrm{kg}$ of DM & 23 & 13 & 15 & 2 \\
\hline $\mathrm{NE}_{\mathrm{J}}{ }^{5} \mathrm{MJ} / \mathrm{kg}$ of DM & 7.7 & 7.6 & 6.9 & 6.8 \\
\hline $\mathrm{OMD}^{6} \%$ & 79.8 & 79.8 & 74.7 & 74.7 \\
\hline
\end{tabular}

${ }^{1}$ High digestibility and high protein concentration (HdHp), high digestibility and low protein concentration (HdLp), low digestibility and high protein concentration (LdHp), and low digestibility and low protein concentration (LdLp).

${ }^{2}$ Including monocalcium phosphate and sodium chloride.

${ }^{3}$ Predicted AA absorbed in the small intestine at $20 \mathrm{~kg}$ of DMI (Volden, 2011).

${ }^{4}$ Protein balance in the rumen at $20 \mathrm{~kg}$ of DMI (Volden, 2011).

${ }^{5} \mathrm{NE}_{\mathrm{L}}$ is calculated according to Weisbjerg and Hvelplund (1993).

${ }^{6} \mathrm{OMD}=$ estimated in vivo $\mathrm{OM}$ digestibility; calculated from measured in vitro digestibility according to Åkerlind et al. (2011). 
ether (Soxtec 2050, Foss Analytical, Hillerød, Denmark) after hydrolysis with $\mathrm{HCl}$ (Stoldt, 1952). Ash-free NDF was measured using a Fibertec M6 System (Foss Analytical) using heat-stable $\alpha$-amylase and sodium sulfite as described by Mertens (2002). Total sugar in grass silage was analyzed by the Luff-Schoorl method (71/250/EEC; Schoorl, 1929) and starch was measured by an enzymatic colorimetric technique (Knudsen et al., 1987).

The concentration of VFA in forage samples was analyzed according to the method described by Canibe et al. (2007) using a Hewlett Packard GC (model 6890) equipped with a flame-ionization detector and a 30-m SGE BP1 column (Scientific Instrument Services, Ringoes, NJ). The concentration of ethanol was analyzed as described by Beutler (1984). For determination of $\mathrm{NH}_{3}$, the feed was alkalized with $\mathrm{KOH}$, and $\mathrm{NH}_{3}$ was determined by titration after distillation using a Kjeltec 2400 (Foss Analytical). The FA content of individual feed items was analyzed as described by Larsen et al. (2013).

In vitro digestibility of $\mathrm{OM}$ in forages was determined by anaerobic incubation with diluted rumen fluid for $48 \mathrm{~h}$, followed by incubation of undissolved material with pepsin HCl-solution for $48 \mathrm{~h}$ (Tilley and Terry, 1963). In vitro digestibility of OM of concentrates was determined by treating samples with pepsin- $\mathrm{HCl}$ solution followed by incubation with cellulytic enzymes (Weisbjerg and Hvelplund, 1993).

Feed Intake. Individual intakes of mixed ration and concentrate fed in the AMS were calculated daily. The total daily concentrate allowance (maximum $3 \mathrm{~kg}$ ) allocated at each visit in the AMS was proportional to the length of time since the last milking for the individual cow. Concentrate was offered at a rate of 400 $\mathrm{g} / \mathrm{min}$, and cows were allowed up to $50 \%$ of the daily concentrate ration per visit. It was possible for the cows to carry over $50 \%$ of daily concentrate allowance to the next day. The individual concentrate intake was calculated as the amount of concentrate offered corrected for recorded individual refusals.

Milk Yield and Quality. Milk yield was measured at every visit in the AMS using the DeLaval Free Flow meter MM25 (DeLaval AB) based on optical milk flow measurement. Every week, representative milk samples were taken at each milking during a 48 -h period. Samples were analyzed for protein, fat, and lactose contents on a Milkoscan 4000 infrared analyzer at Eurofins Steins (Holstebro, Denmark). The analyzed milk samples and the corresponding milk yield recordings were used to calculate average concentrations of protein, fat, and lactose. Lactose was expressed as lactose monohydrate, with the energy factor as given by Sjaunja et al. (1991).

Milk urea was analyzed using flow injection analysis (Nielsen et al., 2005) using a FIAstar 5000 Ana- lyzer (Foss Tecator AB, Höganäs, Sweden). Urease (EC 3.5.1.5, Toyobo Enzymes Ltd., Osaka, Japan) was added to the diluted milk sample. After hydrolysis of urea, a strong alkali solution was added and the developed ammonia was dialyzed through a membrane. $\mathrm{pH}$ changes in the passing aqueous phase were followed via a $\mathrm{pH}$ indicator by spectrophotometer. User instructions given by the manufacturer were followed (Foss Tecator $\mathrm{AB}$ ).

For analysis of milk FA, proportionate amounts of the milk samples taken during a 48-h period (see above) in the last week of each experimental period were pooled to obtain 1 milk sample per cow. Composite samples were frozen and stored at $-18^{\circ} \mathrm{C}$ until analysis. The FA composition of the milk fat was analyzed as described by Larsen et al. (2013), except that heptane was used as solvent instead of pentane.

Blood Samples. Blood samples were collected on the last day of each feeding period. Six animals on each ration were randomly selected and samplings on these animals were repeated every feeding period. Blood samples were taken by vein puncture from the jugular vein $(\mathbf{J V})$ and milk vein (MV) between 1030 and $1430 \mathrm{~h}$ and were collected in EDTA tubes, after which plasma was separated by centrifugation at $2,000 \times g$ for 15 min at $4^{\circ} \mathrm{C}$ and stored at $-20^{\circ} \mathrm{C}$ until analyzed. Blood samples were analyzed for cholesterol, triglyceride, urea, serum $\gamma$-glutamyltransferase (GGT), butyrate, NEFA, lactate, and glucose as described by Khanal et al. (2014). The concentration in the JV was used as a measure of systemic arterial concentrations because differences in plasma concentrations for the metabolites studied in JV and arterial vessels are insignificant, and the arterio-venous difference was estimated as the difference between the JV and MV concentrations (Nielsen et al., 2001).

$\boldsymbol{B} \boldsymbol{W}$ and $\boldsymbol{B C S}$. Cows were automatically weighed at each visit in the AMS, and data were treated according to Bossen et al. (2009). Furthermore, all cows were scored for BCS once in each period, based on the visual method described by Ferguson et al. (1994). This method operates with 0.25 -point intervals on the scale from 1 to 5 .

\section{Calculations and Statistical Analysis}

Net energy content of feedstuffs was measured as Scandinavian Feed Units (SFU) and converted to $\mathrm{NE}_{\mathrm{L}}$ $(\mathrm{MJ} / \mathrm{kg}$ of $\mathrm{DM})$ using the fixed conversion coefficient 7.89 MJ of $\mathrm{NE}_{\mathrm{L}} / \mathrm{SFU}$ (Weisbjerg and Hvelplund, 1993; Bossen et al., 2009).

Energy-corrected milk (3.140 MJ $/ \mathrm{kg})$ was calculated as described by Sjaunja et al. (1991) using the following equation: ECM yield $(\mathrm{kg})=$ milk yield $(\mathrm{kg}) \times[(38.3 \times$ 
fat $(\mathrm{g} / \mathrm{kg})+24.2 \times$ protein $(\mathrm{g} / \mathrm{kg})+15.71 \times$ lactose $(\mathrm{g} / \mathrm{kg})+20.7) / 3,140]$. Energy efficiency was calculated as $\operatorname{ECM}(\mathrm{kg} / \mathrm{d}) / \mathrm{NE}_{\mathrm{L}}(\mathrm{MJ} / \mathrm{d})$, and $\mathrm{N}$ efficiency $\left(\mathrm{N}_{\text {milk }} /\right.$ $\left.\mathrm{N}_{\text {intake }}\right)$ as [(milk protein $\left.(\mathrm{kg} / \mathrm{d}) / 6.38\right] / \mathrm{N}$ intake $(\mathrm{kg} / \mathrm{d})$.

Experimental data were analyzed with the MIXED procedure of SAS software (version 9.2, 2010; SAS Institute Inc., Cary, NC), where model parameters included fixed effect of period (1-4), fixed effect of lactation number $(\mathbf{l} ; \mathbf{1}-4)$, fixed effect of digestibility (d; $\mathrm{Hd}, \mathrm{Ld}$ ), fixed effect of CP concentration ( $\mathbf{p} ; \mathrm{Hp}, \mathrm{Lp}$ ), interaction between digestibility and $\mathrm{CP}$ concentration, interaction between lactation number and digestibility, and interaction between lactation number and CP concentration; cow (1-48) was treated as a random variable. Residuals were assumed normally distributed with mean value 0 and constant variance $\varepsilon \sim N\left(0, \sigma^{2}\right)$. For analysis on milk yield and composition, AMS visit frequency, energy and protein efficiency, and concentrations in jugular vein and jugular-milk vein (JMV) difference across the mammary gland, the following parameters were excluded: interaction between lactation number and digestibility and interaction between lactation number and CP concentration, due to lack of significance $(P>0.10)$. For milk yield and composition, AMS visit frequency, and energy and protein efficiency significance levels were $P>0.12$ for $\mathrm{d} \times \mathrm{l}$ and $P>0.11$ for $\mathrm{p} \times 1$, and for concentrations in the jugular vein and JMV difference across the mammary gland, $P$-values were $>0.17$ for $\mathrm{d} \times 1$ and $P>0.38$ for $\mathrm{p} \times 1$.

To test if a given cow's milk production level affected its sensitivity to the protein supply and digestibility, the mean milk yield per cow was calculated. The difference in ECM between $\mathrm{Hp}$ and $\mathrm{Lp}$ was calculated for each cow: $\left(\mathrm{ECM}_{\mathrm{HdHp}}+\mathrm{ECM}_{\mathrm{LdHp}} / 2\right)-\left(\mathrm{ECM}_{\mathrm{HdLp}}\right.$ $\left.+\mathrm{ECM}_{\mathrm{LdLp}} / 2\right)$; and the difference in ECM between $\mathrm{Hd}$ and Ld was calculated for each cow: $\left(\mathrm{ECM}_{\mathrm{HdHp}}+\right.$ $\left.\mathrm{ECM}_{\mathrm{HdLp}} / 2\right)-\left(\mathrm{ECM}_{\mathrm{LdHp}}+\mathrm{ECM}_{\mathrm{LdLp}} / 2\right)$. The difference values for protein and digestibility were analyzed in PROC GLM as a simple regression on mean milk yield of the cow.

Results reported in tables are, if not otherwise stated, treatment least squares means (LSM) and standard errors of mean (SEM). Multiple comparisons of treatment means were performed using PDIFF in SAS, if $P$ $\leq 0.05$ for the interaction between digestibility and $\mathrm{CP}$ concentration; $P$-values $\leq 0.05$ were regarded as significant, $P \leq 0.10$ as tendencies.

\section{RESULTS}

\section{Feed Intake}

The chemical composition of feedstuffs is shown in Table 1 and silage quality in Table 2. Ration ingredients and chemical compositions are shown in Table 3.
Total feed intake (DM and $\mathrm{NE}_{\mathrm{L}}$ ) was affected by treatment, with an interaction between digestibility and $\mathrm{CP}(P<0.05)$, where the effect of dietary protein concentration was smaller at low digestibility than at high digestibility (Table 4 ). When digestibility decreased, total DMI also decreased, from 24.4 to 22.1 $\mathrm{kg}$ of $\mathrm{DM} / \mathrm{d}(P<0.001$, SEM 0.37). Likewise, when the CP concentration decreased, total DMI decreased, from 23.6 to $22.8 \mathrm{~kg} \mathrm{DM} / \mathrm{d}(P<0.001$, SEM 0.37). The combination of low digestibility and low CP concentration thus resulted in the lowest total DMI of $21.9 \mathrm{~kg} / \mathrm{d}$ (SEM 0.38 ). Low forage digestibility increased concentrate intake in the AMS from 2.2 to 2.4 $\mathrm{kg}$ of $\mathrm{DM} / \mathrm{d}(P<0.005$, SEM 0.05; Table 4$)$. Dietary $\mathrm{CP}$ content did not affect concentrate intake. The response in DMI to increased digestibility in the ration was greater for older cows than for first-lactation cows $(P=0.003)$, as the increase in DMI from $\mathrm{Ld}$ to Hd was $1.5 \mathrm{~kg}$ (SEM 0.48), $2.8 \mathrm{~kg}$ (SEM 0.62), $2.5 \mathrm{~kg}$ (SEM 0.62), and $2.5 \mathrm{~kg}$ (SEM 1.1) of DMI/d for first-, second-, third-, and fourth-lactation cows, respectively (data not shown).

\section{Milk Yield and Quality, BW, and BCS}

Data on milk yield and composition are given in Table 5. Daily ECM yield increased from $32.4 \mathrm{~kg} / \mathrm{d}$ on $\mathrm{Ld}$ to $34.1 \mathrm{~kg} / \mathrm{d}$ on the Hd ration $(P<0.001$, SEM 0.87 ) and from $32.7 \mathrm{~kg} / \mathrm{d}$ on $\mathrm{Lp}$ to $33.8 \mathrm{~kg} / \mathrm{d}$ on the Hp ration $(P=0.003$, SEM 0.87). Increased lactation number increased milk yield $(P=0.002)$, with ECM yields of 27.8 (SEM 1.12), 32.3 (SEM 1.45), 35.6 (SEM 1.45 ), and 37.4 (SEM 2.51) kg/d for first-, second-, third-, and fourth-lactation cows, respectively (data not shown). The milk fat percentage decreased with increased forage digestibility from 4.26 to $4.12 \%(P<$ 0.001, SEM 0.08), whereas the milk protein percentage increased with increased forage digestibility from 3.56 to $3.62 \%(P<0.001$, SEM 0.04). The urea content in milk was higher when the high $\mathrm{CP}$ concentration rations were fed (3.32 vs. $2.54 \mathrm{~m} M$ urea; $P<0.001$, SEM 0.04). Concentrations of individual FA in milk were affected by forage digestibility, where increased digestibility resulted in higher concentrations of medium-chain (C10-C14) FA (23.1 vs. $22.4 \mathrm{~g} / 100 \mathrm{~g}$ of FA; $P<0.001$, SEM 0.19), odd-chain (C11-C17) FA $(2.9$ vs. $2.7 \mathrm{~g} / 100 \mathrm{~g}$ of FA; $P<0.001$, SEM 0.04), and C18 FA (27.3 vs. $26.3 \mathrm{~g} / 100 \mathrm{~g}$ of FA; $P=0.005$, SEM 0.33). Additionally, Hd resulted in lower concentrations of short-chain (C4-C8) FA (9.9 vs. $10.3 \mathrm{~g} / 100 \mathrm{~g}$ of FA; $P=0.002$, SEM 0.11) and C16 FA (35.4 vs. $36.9 \mathrm{~g} / 100$ $\mathrm{g}$ of FA; $P<0.001$, SEM 0.35) compared with Ld. A higher dietary $\mathrm{CP}$ concentration decreased C16 FA concentrations from 36.9 to $35.4 \mathrm{~g} / 100 \mathrm{~g}$ of FA $(P<$ 
Table 4. Feed intake of mixed ration, concentrate, and total ration

\begin{tabular}{|c|c|c|c|c|c|c|c|c|c|c|c|}
\hline Item & \multicolumn{4}{|c|}{ Treatment $^{1}$} & SEM & \multicolumn{6}{|c|}{$P$-value ${ }^{2}$} \\
\hline Mixed ration $\mathrm{DM}, \mathrm{kg} / \mathrm{d}$ & 22.7 & 21.6 & 20.1 & 19.5 & 0.38 & $<0.001$ & $<0.001$ & $<0.001$ & 0.06 & 0.009 & 0.43 \\
\hline Total DM, kg/d & $24.9^{\mathrm{a}}$ & $23.8^{\mathrm{b}}$ & $22.4^{\mathrm{c}}$ & $21.9^{\mathrm{d}}$ & 0.38 & $<0.001$ & $<0.001$ & $<0.001$ & 0.04 & 0.003 & 0.37 \\
\hline Total $\mathrm{NE}_{\mathrm{L}}, \mathrm{MJ} / \mathrm{kg}$ of $\mathrm{DM}$ & $191.7^{\mathrm{a}}$ & $181.5^{\mathrm{b}}$ & $155.5^{\mathrm{c}}$ & $150.5^{\mathrm{d}}$ & 2.74 & $<0.001$ & $<0.001$ & $<0.001$ & 0.02 & $<0.001$ & 0.32 \\
\hline Total CP, $\mathrm{kg} / \mathrm{d}$ & $4.0^{\mathrm{a}}$ & $3.4^{\mathrm{b}}$ & $3.5^{\mathrm{c}}$ & $3.1^{\mathrm{d}}$ & 0.06 & $<0.001$ & $<0.001$ & $<0.001$ & 0.004 & 0.005 & 0.14 \\
\hline
\end{tabular}

${ }^{\mathrm{a}-\mathrm{d}}$ Means within a row with different superscripts are significantly different $(P<0.05)$.

${ }^{1}$ High digestibility and high $\mathrm{CP}$ concentration (HdHp), high digestibility and low CP concentration (HdLp), low digestibility and high CP concentration (LdHp), and low digestibility and low CP concentration (LdLp).

${ }^{2}$ Lactation number (l), digestibility (d), and crude protein (p).

${ }^{3}$ Predicted AA absorbed in the small intestine at $20 \mathrm{~kg}$ of DMI (Volden, 2011).

0.001, SEM 0.35) and increased C18 FA from 26.1 to $27.4 \mathrm{~g} / 100 \mathrm{~g}$ of FA $(P<0.001$, SEM 0.33$)$.

Lower forage digestibility resulted in a greater frequency of visits to the AMS (2.33 vs. 2.25 visits/d; $P=0.05$, SEM 0.08). Energy efficiency was higher for cows fed forage with a low digestibility $(0.22 \mathrm{~kg}$ of $\mathrm{ECM} / \mathrm{MJ}$ of $\mathrm{NE}_{\mathrm{L}}$ ) compared with cows fed forage with a high digestibility $\left(0.18 \mathrm{~kg}\right.$ of $\mathrm{ECM} / \mathrm{MJ}$ of $\mathrm{NE}_{\mathrm{L}}$; $P<0.001$, SEM 0.005) and energy efficiency was not affected by the CP concentration. Nitrogen efficiency decreased with higher $\mathrm{CP}$ concentrations (0.31 vs. 0.35 $\mathrm{kg}$ of $\mathrm{N}_{\text {milk }} / \mathrm{N}_{\text {intake }} ; P<0.001$, SEM 0.008).
Average BW changed from 643 to $667 \mathrm{~kg}$ throughout the experiment $(84 \mathrm{~d})$, resulting in an average daily gain of $278 \mathrm{~g}$; at the same time the BCS changed from 2.9 to 3.0 .

\section{Blood Parameters}

Data on concentrations in the JV and the JMV difference across the mammary gland are given in Table 6 . Increased forage digestibility was associated with increased plasma levels of cholesterol from 5.24 to 5.46 $\mathrm{mmol} / \mathrm{L}(P=0.005$, SEM 0.23) and a decrease from

Table 5. Milk yield and composition, automatic milking system (AMS) visit frequency, and energy and protein efficiency ${ }^{1}$

\begin{tabular}{|c|c|c|c|c|c|c|c|c|c|}
\hline \multirow[b]{2}{*}{ Item } & \multicolumn{4}{|c|}{ Treatment $^{2}$} & \multirow[b]{2}{*}{ SEM } & \multicolumn{4}{|c|}{$P$-value ${ }^{3}$} \\
\hline & HdHp & HdLp & $\mathrm{LdHp}$ & LdLp & & $\mathrm{d}$ & $\mathrm{p}$ & 1 & $\mathrm{~d} \times \mathrm{p}$ \\
\hline $\mathrm{ECM}, \mathrm{kg} / \mathrm{d}$ & 34.8 & 33.5 & 32.9 & 31.9 & 0.90 & $<0.001$ & 0.003 & 0.002 & 0.78 \\
\hline Milk fat, $\%$ & 4.10 & 4.13 & 4.24 & 4.29 & 0.08 & $<0.001$ & 0.10 & 0.81 & 0.66 \\
\hline Milk protein, \% & 3.63 & 3.62 & 3.57 & 3.55 & 0.05 & $<0.001$ & 0.09 & 0.04 & 0.75 \\
\hline Lactose, ${ }^{4} \%$ & 4.85 & 4.86 & 4.81 & 4.80 & 0.02 & $<0.001$ & 0.91 & 0.001 & 0.11 \\
\hline \multicolumn{10}{|l|}{ Fatty acids, g/100 g of FA } \\
\hline Short chain: $\mathrm{C} 4+\mathrm{C} 6+\mathrm{C} 8$ & 9.8 & 10.0 & 10.2 & 10.4 & 0.13 & 0.002 & 0.06 & 0.11 & 0.96 \\
\hline Medium chain: $\mathrm{C} 10+\mathrm{C} 12+\mathrm{C} 14+\mathrm{C} 14: 1$ & 23.3 & 23.0 & 22.5 & 22.3 & 0.21 & $<0.001$ & 0.06 & 0.66 & 0.78 \\
\hline Odd chain: $\mathrm{C} 11+\mathrm{C} 13+\mathrm{C} 15+\mathrm{C} 17+\mathrm{C} 17: 1$ & 2.9 & 2.9 & 2.8 & 2.7 & 0.04 & $<0.001$ & 0.76 & 0.03 & 0.07 \\
\hline C16 FA: C16 + C16:1 & 34.9 & 36.0 & 36.1 & 37.7 & 0.38 & $<0.001$ & $<0.001$ & 0.65 & 0.23 \\
\hline C18 FA: C18 + C18:1 + C18:2 + C18:3 & 27.8 & 26.7 & 27.1 & 25.6 & 0.38 & 0.005 & $<0.001$ & 0.43 & 0.47 \\
\hline Visits to AMS $\left(\mathrm{d}^{-1}\right)$ & 2.27 & 2.23 & 2.32 & 2.34 & 0.08 & 0.047 & 0.85 & 0.98 & 0.47 \\
\hline
\end{tabular}

${ }^{1}$ Interaction between lactation number and digestibility and between lactation number and $\mathrm{CP}$ concentration were excluded from the model due to lack of significance $(P>0.11)$. One exception was C18 FA, where $P=0.04$ for $1 \times \mathrm{d}$.

${ }^{2}$ High digestibility and high $\mathrm{CP}$ concentration (HdHp), high digestibility and low $\mathrm{CP}$ concentration (HdLp), low digestibility and high CP concentration ( $\mathrm{LdHp}$ ), and low digestibility and low CP concentration (LdLp).

${ }^{3}$ Lactation number (1), digestibility (d), and crude protein (p).

${ }^{4}$ Lactose is expressed as lactose monohydrate, with the energy factor as given by Sjaunja et al. (1991).

${ }^{5}$ Calculated as $\mathrm{N}_{\text {milk }} / \mathrm{N}_{\text {intake }}=[$ milk protein $(\mathrm{kg} / \mathrm{d}) / 6.38] /[\mathrm{N}$ intake $(\mathrm{kg} / \mathrm{d})]$. 
3.69 to $3.12 \mathrm{mmol} / \mathrm{L}(P=0.005$, SEM 0.18$)$ in plasma levels of urea in the JV. An increased dietary CP concentration in the ration decreased JV plasma levels of cholesterol from 5.45 to $5.25 \mathrm{mmol} / \mathrm{L}(P=0.009$, SEM 0.22 ) and increased JV plasma levels of urea from 2.91 to $3.91 \mathrm{mmol} / \mathrm{L}(P<0.001$, SEM 0.18), respectively. The higher $\mathrm{CP}$ concentration also decreased plasma levels of triglyceride from 0.22 to $0.20 \mathrm{mmol} / \mathrm{L}(P=$ 0.04, SEM 0.006) and GGT from 40.5 to $37.8 \mathrm{mmol} / \mathrm{L}$ $(P=0.04$, SEM 2.74), and tended to increase NEFA from 0.31 to $0.42 \mathrm{mmol} / \mathrm{L}(P=0.08$, SEM 0.05$)$.

We observed no effects of forage digestibility or $\mathrm{CP}$ concentration in the ration on JMV differences for the different metabolites (see Table 6), except for glucose $(P=0.05$, SEM 0.08), where JMV differences were lower on rations with high digestibility $(0.56 \mathrm{mmol} / \mathrm{L})$ compared with rations with low digestibility (0.73 $\mathrm{mmol} / \mathrm{L})$. The JMV differences for triglyceride tended to be lower $(P=0.09$, SEM 0.005$)$ when digestibility was increased (0.036 vs. $0.046 \mathrm{mmol} / \mathrm{L})$.

Lactation number affected the concentration in the jugular vein only for triglyceride $(P=0.05)$, with higher concentrations in first-lactation cows $(0.24 \mathrm{mmol} / \mathrm{L}$, SEM 0.01) compared with second- $(0.20 \mathrm{mmol} / \mathrm{L}, \mathrm{SEM}$ $0.006)$ and third- $(0.19 \mathrm{mmol} / \mathrm{L}, \mathrm{SEM} 0.007)$ lactation cows. The JMV differences for glucose were higher $(P$ $=0.005)$ for first-lactation cows $(0.98 \mathrm{mmol} / \mathrm{L}$, SEM $0.18)$ than for second- $(0.40 \mathrm{mmol} / \mathrm{L}, \mathrm{SEM} 0.07)$ and third- $(0.56 \mathrm{mmol} / \mathrm{L}$, SEM 0.08) lactation cows, and this was also the case for triglyceride $(P=0.02)$, with
JMV differences in first-lactation cows of $0.068 \mathrm{mmol} / \mathrm{L}$ (SEM 0.01) compared with $0.023 \mathrm{mmol} / \mathrm{L}$ (SEM 0.005) in second-lactation cows and $0.031 \mathrm{mmol} / \mathrm{L}$ (SEM 0.005) in third-lactation cows.

\section{DISCUSSION}

\section{Rations and Intake}

We expected that low CP concentration as well as low forage digestibility would reduce the DMI. Protein requirement is determined by the cow's requirement for AA for protein synthesis in different tissues and the requirement for RDP to sustain microbial protein synthesis in the rumen. The DMI for lactating cows is often positively related to the protein concentration in the ration (Oldham, 1984; Broderick, 2003; Habib et al., 2006; Weisbjerg et al., 2010). In the present study, DMI increased by $0.8 \mathrm{~kg}(P<0.001$, SEM 0.37$)$ when the $\mathrm{CP}$ concentration was increased from approximately 14.0 to $15.9 \%$, due to an increase in intake of mixed ration.

It has been suggested that RDP fed under the level needed to sustain ruminal microorganisms may negatively affect intake due to depression of ruminal digestion (Olmos Colmenero and Broderick, 2006; Lee et al., 2012). Increased dietary CP content increases fiber digestibility and thereby DM digestibility of the feed, partly due to increased RDP effects on the digestibility of feedstuffs (Oldham, 1984; Allen, 2000),

Table 6. Concentrations in jugular vein and jugular-milk venous (JMV) difference across the mammary gland ${ }^{1}$

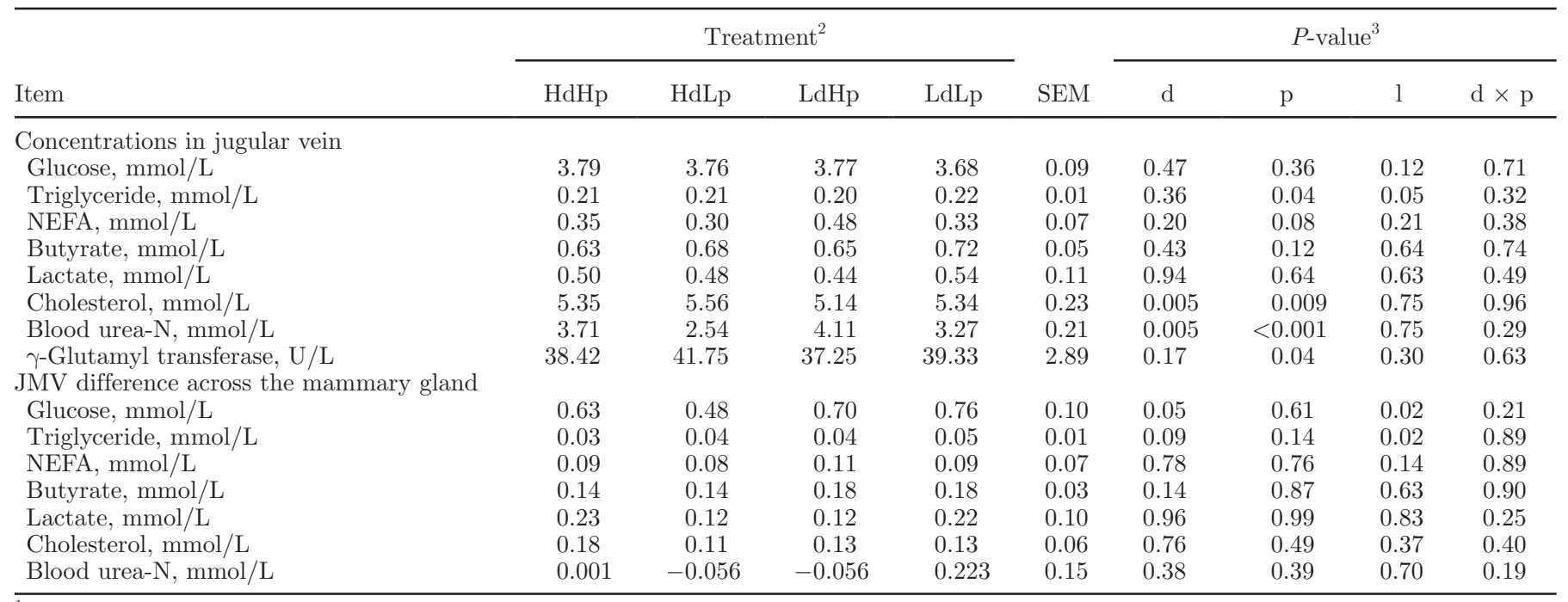

${ }^{1}$ Interaction between lactation number and digestibility and between lactation number and CP concentration were excluded from the model, due to lack of significance $(P>0.17)$. One exception was JMV difference of cholesterol where $P=0.04$ for $\mathrm{p} \times 1$.

${ }^{2}$ High digestibility and high $\mathrm{CP}$ concentration (HdHp), high digestibility and low $\mathrm{CP}$ concentration (HdLp), low digestibility and high CP concentration (LdHp), and low digestibility and low CP concentration (LdLp).

${ }^{3}$ Lactation number (l), digestibility (d), and crude protein (p). 
although the marginal response diminishes if the $\mathrm{CP}$ concentration increases and is expected to be minimal when the CP concentration exceeds $15 \%$ of DM. The marginal increase may still be positive when the CP content exceeds 20\% (Oldham, 1984), probably due to the replacement of starch with $\mathrm{CP}$, as starch may have a negative effect on the rumen. Increased ruminal digestibility of the feed is assumed to be responsible for increased DMI up to approximately $15 \%$ dietary CP. Roffler et al. (1986) evaluated different studies to predict responses in DMI to increased content of dietary CP. They found an exponential decline in the increase of DMI per percentage unit increase of CP. At $18 \% \mathrm{CP}$ they predicted that the increase in DMI would more or less disappear. A possible reason for the increase in DMI at high dietary $\mathrm{CP}$ concentration could be a reduction in rumen propionate production as protein is substituted for starch in the ration (Allen, 2000). When protein is oversupplied it may represent a loss of urea energy to the urine, plus the transformation of excess protein into urea is energy-demanding.

Hristov et al. (2002) found that DMI was strongly related to intake of total digestible nutrients or intake of $\mathrm{NE}_{\mathrm{L}}$ (metabolizable energy). In the present study, DMI was reduced by $0.7 \mathrm{~kg}$ for $\mathrm{Ld}$ compared with $\mathrm{Hd}$ rations $(P<0.001$, SEM 0.37). This could also be due to a higher fill value, defined by NDF, in the $\mathrm{Ld}$ ration (396 g of $\mathrm{NDF} / \mathrm{kg}$ of $\mathrm{DM})$ compared with $\mathrm{Hd}$ (319 g of NDF $/ \mathrm{kg}$ of DM). Negative effects on DMI of low grass digestibility (mature grass) have been reported in previous studies (Kuoppala et al., 2008, 2010).

Weisbjerg et al. (2010) compared recent studies where forages with high digestibility were used with earlier studies where forages with lower digestibility were used, and concluded that cows eating rations containing forages with high digestibility were less sensitive to low protein concentration than cows eating rations containing forages with low digestibility. This gave rise to the hypothesis that the moderate effect of protein supply on DMI was caused by a progression in forage digestibility and quality. The more pronounced effect of protein supplementation on high- than on low-digestibility rations on DMI is in contrast to the proposed hypothesis. In the present study, low dietary CP content had a less negative effect on DMI when forage digestibility was low $(-0.5 \mathrm{~kg}$ of $\mathrm{DM} / \mathrm{d})$ than when forage digestibility was high $(-1.1 \mathrm{~kg}$ of $\mathrm{DM} / \mathrm{d})$, which was the reverse of the hypothesis. It seems that energy supply from the lower digestible forage was more limiting for DMI than for protein $(\mathrm{N})$. This was probably because the high microbial synthesis of the high-digestible silage increased the requirement for RDP. Furthermore, the RDP supply on LdLp, although low, was probably not limiting for rumen digestion. Protein balance in the rumen at 20 $\mathrm{kg}$ of DMI $\left(\mathrm{PBV}_{20}\right)$ ranged from 13 to $23 \mathrm{~g} / \mathrm{kg}$ of DM for $\mathrm{Hd}$ and 2 to $15 \mathrm{~g} / \mathrm{kg}$ of DM for Ld. The differences in $\mathrm{PBV}_{20}$ values between $\mathrm{Hd}$ and Ld were mainly due to supplementation of urea to the Hd rations.

\section{Milk Yield and Quality}

The frequency of visits to the AMS was higher when the cows were fed rations with low forage digestibility (2.33 visits/d) compared with high forage digestibility (2.25 visits $/ \mathrm{d} ; P=0.05$, SEM 0.08$)$, probably because a less-digestible mixed ration makes the concentrate in the AMS more attractive. However, the difference was numerically small and probably had only a minor effect on milk yield and composition.

Olmos Colmenero and Broderick (2006) found that increased dietary protein concentration can stimulate milk yield without affecting DMI, probably due to an increased digestibility, because they found a quadratic effect $(P<0.01)$ of the CP concentration on OMD. Weisbjerg et al. (2012) observed a more pronounced increase in milk production than in DMI when increasing the protein concentration in the diet. They found that the response in milk yield was higher for high-yielding cows than for lower-yielding cows. In the present study, sensitivity to CP supply was not affected significantly by the cows' level of milk production, as the difference in milk production between $\mathrm{Lp}$ and $\mathrm{Hp}$ increased by only $0.017 \mathrm{~kg}$ of ECM per 1-kg increase in cow milk production level $(P=0.8)$. The difference between $\mathrm{Ld}$ and $\mathrm{Hd}$ increased with $0.25 \mathrm{~kg}$ of $\mathrm{ECM}$ per $1-\mathrm{kg}$ increase in cow milk production level $(P=0.001)$. The increased sensitivity to digestibility should probably be seen in relation to a higher DMI on Hd than Ld. We detected no interaction between $\mathrm{CP}$ concentration and lactation number or digestibility and lactation number. Normally, the response to increased nutrient supply is higher in older cows (Smith et al., 1978; Bossen and Weisbjerg, 2009).

Composition of milk was affected by both forage digestibility and $\mathrm{CP}$ concentration in the ration, such that the milk fat percentage was higher on the lowdigestibility ration (4.26\%) compared with the highdigestibility ration $(4.12 \% ; P<0.001$, SEM 0.08). Veerkamp et al. (1994) also found this difference in milk fat percentage between low (4.44\%) and high energy rations $(4.11 \%)$, which can be explained by a dilution in volume when yield is increased. The dietary protein level has little effect on milk fat concentration within the normal range of supplementation (Veerkamp et al., 1994), and in our study there was only a tendency for low dietary $\mathrm{CP}$ concentration to increase milk fat, from 4.17 to $4.21 \%$ ( $P<0.1$, SEM 0.08). Moreover, changes in protein supply within the normal range seldom affect 
milk protein concentration appreciably (Sutton, 1989), which agrees with the current study where Hp tended to have higher milk protein concentration $(3.60 \%)$ than Lp $(3.58 \% ; P=0.09$, SEM 0.04). By supplementation of AA to the ration, it is possible to increase the protein concentration in milk, as shown by Robinson (2010), however, depending on the $\mathrm{CP}$ level in the control ration. Milk protein concentration was lower on the $\mathrm{Ld}$ rations $(3.56 \%)$ than on the $\mathrm{Hd}$ rations $(3.62 \%$; $P<$ 0.001, SEM 0.04), which is in agreement with Rinne et al. (1999), who reported that milk protein concentrations increase when high-digestibility silages are fed and that this is coupled to an overall improved energy status and increased intestinal supply of AA to the cow. The urea concentration increased as expected with an increased concentration of $\mathrm{CP}$ in the rations (from 2.54 to $3.32 \mathrm{mM} ; P<0.001$, SEM 0.04), as also shown by Groff and $\mathrm{Wu}(2005)$.

The observed effects of treatments on milk FA composition were generally minor (relative changes of $3-5 \%$ ) compared with other feeding experiments, especially those where different fat supplements have been investigated (Larsen et al., 2013). The C18 FA content of the Hd rations was higher than on Ld rations (15.5 vs. $12.8 \mathrm{~g} / \mathrm{kg}$ of DM) and this resulted in higher content of C18 FA (27.3 vs. $26.3 \mathrm{~g} / 100 \mathrm{~g}$ of FA; $P=0.005$, SEM 0.33 ) and lower content of C16 FA (35.4 vs. $36.9 \mathrm{~g} / 100$ $\mathrm{g}$ of FA; $P<0.001$, SEM 0.35) in milk from cows on $\mathrm{Hd}$ rations. The differences in short- and medium-chain FA in milk from cows on $\mathrm{Hd}$ and $\mathrm{Ld}$ rations showed that a higher proportion of these were short-chain FA when the concentration of $\mathrm{C} 18 \mathrm{FA}$ in milk fat was higher. The differences in FA composition in milk from cows on $\mathrm{Hp}$ and Lp rations were limited to a higher content of C18 FA in milk from cows on Hp compared with cows on Lp (27.4 vs. $26.1 \mathrm{~g} / 100 \mathrm{~g}$ of FA; $P<0.001$, SEM 0.33 ) and a lower content of C16 FA in milk from cows on Hp compared with cows on Lp (35.5 vs. $36.9 \mathrm{~g} / 100$ $\mathrm{g}$ of FA; $P<0.001$, SEM 0.35), which was a reflection of the difference in $\mathrm{C} 18 \mathrm{FA}$ content of the $\mathrm{Hp}$ and $\mathrm{Lp}$ rations (14.83 vs. $13.55 \mathrm{~g} / \mathrm{kg}$ of DM).

Based on mean values, the balance between FA intake from feed and FA secretion in milk was calculated and the intake of $\mathrm{C} 16$ corresponded to 14 to $17 \%$ of the output of C16 FA in milk; thus, at least $83 \%$ of the C16 in milk was derived from de novo synthesis. For C18 FA, the intake from feed relative to the output in milk corresponded to 109 and 104\% for the HdHp and HdLp treatments, respectively, whereas it was 87 and $86 \%$ for the LdHp and LdLp treatments. These results show that the fat supply from feed was low and the de novo synthesis was high, and for the Ld treatments part of the $\mathrm{C} 18 \mathrm{FA}$ in milk did not derive directly from the feed. The other main source of C18 FA is from the body fat turnover and as cows did not lose weight or score lower for body condition, a net body synthesis of C18 FA had occurred.

\section{Nutrient Provision to and Extraction by the Mammary Gland}

The plasma level of urea increased for cows fed the $\mathrm{Ld}(3.69 \mathrm{mmol} / \mathrm{L})$ compared with the $\mathrm{Hd}(3.12$ $\mathrm{mmol} / \mathrm{L})$ ration $(P=0.005$, SEM 0.18$)$, and this was also reflected in milk urea levels. Plasma urea levels are generally believed to reflect hepatic urea synthesis, which, in turn, is coupled to hepatic AA oxidation and absorption of ammonia from forestomach fermentation. It appears unlikely that microbial protein or ammonia synthesis should have been increased due to decreased ration digestibility, where both fermentable OM and dietary urea supply were limited compared with the high-digestibility rations. Therefore, one explanation for the higher plasma levels of urea on Ld rations could be that digestibility was more depressed than supply of $\mathrm{N}$, and therefore less $\mathrm{N}$ would be captured in the rumen, leading to a possible increase in plasma urea. Another explanation could be increased hepatic AA oxidation, although it is puzzling that this appears to have occurred despite a decreased surplus of AA [estimated as intake of AA absorbed in the small intestine at $20 \mathrm{~kg}$ of DMI $\left(\mathrm{AAT}_{20}\right)$ minus milk protein output] on Ld compared with Hd rations.

We cannot explain the dietary effects on plasma cholesterol. The higher plasma cholesterol on the Lp rations $(5.45 \mathrm{mmol} / \mathrm{L})$ compared with the $\mathrm{Hp}$ rations $(5.25$ $\mathrm{mmol} / \mathrm{L} ; P=0.009$, SEM 0.22) was associated with higher plasma levels of GGT (40.5 vs. $37.8 \mathrm{mmol} / \mathrm{L}$; $P=0.04$, SEM 2.74) and triglyceride (0.22 vs. 0.20 $\mathrm{mmol} / \mathrm{L} ; P=0.04$, SEM 0.006), which could not be a result of increased fat absorption because the dietary fat content was lower on the Lp ration (13.6 vs. $14.8 \mathrm{~g}$ of $\mathrm{C} 18 / \mathrm{kg}$ of DM). Nor is it likely to be explained by increased hepatic lipoprotein synthesis because GGT (a marker of hepatic function) was increased rather than decreased. The depression in cholesterol on $\mathrm{Hp}$ rations is interesting, as cholesterol plays an important role in the synthesis of membranes. It has been suggested that uptake of cholesterol in the mammary gland may be a limiting factor for the formation of cellular membranes and hence for overall milk secretion (Nielsen and Jakobsen, 1994).

Plasma concentrations in arterial blood of the major organic metabolites utilized for milk synthesis in the mammary gland closely resembled plasma concentrations found in the JV, as the quantitative utilization of these nutrients in the brain is negligible (Nielsen et al., 2001). Thus, JMV concentration differences for 
the metabolites shown in Table 6 will be equivalent to arterio-venous differences across the mammary gland. The only effect of dietary changes on the uptake of nutrients from plasma in the mammary gland was found for glucose, where both JMV difference and extraction were increased $(P=0.05)$, and JMV also tended to be increased for triglyceride $(P=0.09)$ when forage digestibility was decreased. However, because milk production was lowest on the Ld rations, the quantitative mammary glucose uptake must also have been lower on the Ld diets. According to Madsen et al. (2005), increased efficiency in mammary glucose and triglyceride uptake on the Ld rations could be explained by a compensatory response to a depression of mammary blood flow caused by a decreased mammary AA supply when on a ration with a lower protein supply and $\mathrm{N}$ content. This is, however, unlikely because JMV concentration differences for glucose were independent of changes in dietary $\mathrm{CP}$ concentration, and other studies have shown that mammary glucose uptake is quite independent of arterial glucose supply during the mid-to-late stages of lactation in ruminants (Nielsen et al., 2001). Acetate is the major nutrient generating the physiological energy (ATP) to sustain milk synthetic processes in the mammary gland, and increased supply of acetate to the mammary gland could sustain milk protein synthesis and compensate for insufficient dietary provision of energy and essential AA (Safayi and Nielsen, 2013). Higher mammary glucose extraction on the Ld rations may be linked to a lowered mammary supply and uptake of acetate, because the microbial fermentation in the rumen would be expected to be lower on Ld rations.

\section{CONCLUSIONS}

Lower concentrations of dietary CP and forage digestibility reduced both DMI and milk production. We detected no interactive effect on milk production of CP concentration and forage digestibility, indicating that the reduction in milk production with a lower $\mathrm{CP}$ concentration could not be compensated by increased forage digestibility.

\section{ACKNOWLEDGMENTS}

The work was funded by the Danish Ministry of Food, Agriculture and Fisheries (GUDP, Copenhagen, Denmark), the Danish Cattle Federation (Aarhus, Denmark), and Aarhus University (Tjele, Denmark).

\section{REFERENCES}

Åkerlind, M., M. R. Weisbjerg, T. Eriksson, R. Tøgersen, P. Udén, B. L. Ólafsson, O. M. Harstad, and H. Volden. 2011. Feed analyses and digestion methods. Pages 41-54 in NorFor-The Nordic Feed Evaluation System. H. Volden, ed. EAAP Publication No. 130. Wageningen Academic Publishers, Wageningen, the Netherlands.

Allen, M. S. 2000. Effects of diet on short-term regulation of feed intake by lactating dairy cattle. J. Dairy Sci. 83:1598-1624.

AOAC International. 2000. Official Methods of Analysis. 15th ed. AOAC International, Washington, DC.

Beutler, H. O. 1984. Ethanol. Pages 598-606 in Methods of Enzymatic Analysis. Vol. VI. 3rd ed. H. U. Bergmeyer, ed. Verlag Chemie, Weinheim, Germany.

Børsting, C. F., T. Kristensen, L. Misciattelli, T. Hvelplund, and M. R. Weisbjerg. 2003. Reducing nitrogen surplus from dairy farms: Effects of feeding and management. Livest. Prod. Sci. 83:165-178.

Bossen, D., and M. R. Weisbjerg. 2009. Allocation of feed based on individual dairy cow live weight changes. II: Effect on milk production. Livest. Sci. 126:273-285.

Bossen, D., M. R. Weisbjerg, L. Munksgaard, and S. Højsgaard. 2009. Allocation of feed based on individual dairy cow live weight changes. I: Feed intake and live weight changes during lactation. Livest. Sci. $126: 252-272$.

Broderick, G. A. 2003. Effects of varying dietary protein and energy levels on the production of lactating dairy cows. J. Dairy Sci. $86: 1370-1381$

Canibe, N., O. Højberg, J. H. Badsberg, and B. B. Jensen. 2007. Effect of feeding fermented liquid feed and fermented grain on gastrointestinal ecology and growth performance in piglets. J. Anim. Sci. 85:2959-2971.

Ferguson, J. D., D. T. Galligan, and N. Thomsen. 1994. Principal descriptors of body condition score in Holstein cows. J. Dairy Sci. 77:2695-2703.

Fisher, D. S. 2002. A review of a few key factors regulating voluntary feed intake in ruminants. Crop Sci. 42:1651-1655.

Groff, E. B., and Z. Wu. 2005. Milk production and nitrogen excretion of dairy cows fed different amounts of protein and varying of alfalfa and corn silage. J. Dairy Sci. 88:3619-3632.

Gross, J., H. A. van Dorland, R. M. Bruckmaier, and F. J. Schwarz. 2011. Milk fatty acid profile related to energy balance in dairy cows. J. Dairy Res. 78:479-488.

Habib, M., J. S. Syed, and J. D. Leaver. 2006. Choice of grass or maize silages by lactating dairy cows: Influence of supplementary protein, concentrate level and milk yield. Anim. Sci. 82:469-477.

Hansen, B. 1989. Determination of nitrogen as elementary-N, an alternative to Kjeldahl. Acta Agric. Scand. 39:113-118.

Hristov, A. N., W. J. Price, and B. Shafii. 2002. An overview of dietary factors influencing dry matter intake and milk and milk protein yields in dairy cows. Pages 147-165 in Proc. Pacific Northwest Animal Nutrition Conference, Vancouver, BC, Canada. C R Press, Portland, OR.

Khanal, P., S. V. Husted, A. M. Axel, L. Johnsen, K. L. Pedersen, M. S. Mortensen, A. H. Kongsted, and M. O. Nielsen. 2014. Late gestation over- and undernutrition predispose for visceral adiposity in response to a post-natal obesogenic diet, but with differential impacts on glucose-insulin adaptations during fasting in lambs. Acta Physiol. (Oxf.) 210:110-126.

Knudsen, K. E. B., P. Áman, and B. O. Eggum. 1987. Nutritive value of Danish-grown barley varieties, I, carbohydrates and other major constituents. J. Cereal Sci. 6:173-186.

Kuoppala, K., M. Rinne, S. Ahvenjärvi, J. Nousiainen, and P. Huhtanen. 2010. The effect of harvesting strategy of grass silage on digestion and nutrient supply in dairy cows. J. Dairy Sci. 93:3253-3263.

Kuoppala, K., M. Rinne, J. Nousiainen, and P. Huhtanen. 2008. The effect of cutting time of grass silage in primary growth and regrowth and the interactions between silage quality and concentrate level on milk production of dairy cows. Livest. Sci. 116:171-182.

Larsen, M. K., U. Kidmose, T. Kristensen, P. Beaumont, and G. Mortensen. 2013. Chemical composition and sensory quality of bovine milk as affected by type of forage and proportion of concentrate in the feed ration. J. Sci. Food Agric. 93:93-99.

Lee, C., A. N. Hristov, K. S. Heyler, T. W. Cassidy, H. Lapierre, G. A. Varga, and C. Parys. 2012. Effects of metabolizable protein sup- 
ply and amino acid supplementation on nitrogen utilization, milk production, and ammonia emissions from manure in dairy cows. J. Dairy Sci. 95:5253-5268.

M'hamed, D., P. Faverdin, and R. Vérité. 2001. Effect of the level and source of dietary protein on intake and milk yield in dairy cows. Anim. Res. 50:205-211.

Madsen, T. G., L. Nielsen, and M. O. Nielsen. 2005. Mammary nutrient uptake in response to dietary supplementation of rumen protected lysine and methionine in late and early lactating dairy goats. Small Rumin. Res. 56:151-164.

Mertens, D. R. 2002. Gravimetric determination of amylase-treated neutral detergent fiber in feeds with refluxing in beakers or crucibles: Collaborative study. J. AOAC Int. 85:1217-1240.

Nielsen, M. O., and K. Jakobsen. 1994. Changes in mammary uptake of free fatty acids, triglyceride, cholesterol and phospholipid in relation to milk synthesis during lactation in goats. Comp. Biochem. Physiol. A Physiol. 109:857-867.

Nielsen, M. O., T. G. Madsen, and A. M. Hedeboe. 2001. Regulation of mammary glucose uptake in goats: Role of mammary gland supply, insulin. IGF-1 and synthetic capacity. J. Dairy Res. 68:337-349.

Nielsen, N. I., T. Larsen, M. Bjerring, and K. L. Ingvartsen. 2005. Quarter health, milking interval, and sampling time during milking affect the concentration of milk constituents. J. Dairy Sci. 88:3186-3200.

Nielsen, N. M., T. Kristensen, P. Nørgaard, and H. Hansen. 2003. The effect of low protein supplementation to dairy cows grazing clover grass during half of the day. Livest. Prod. Sci. 81:293-306.

Oldham, J. D. 1984. Protein-energy interrelationships in dairy cows. J. Dairy Sci. 67:1090-1114.

Olmos Colmenero, J. J. O., and G. A. Broderick. 2006. Effect of dietary crude protein concentration on milk production and nitrogen utilization in lactating dairy cows. J. Dairy Sci. 89:1704-1712.

Rinne, M., S. Jaakkola, K. Kaustell, T. Heikkilä, and P. Huhtanen 1999. Silages harvested at different stages of grass growth v. concentrate foods as energy and protein sources in milk production. Anim. Sci. 69:251-263.

Robinson, P. H. 2010. Impacts of manipulating ration metabolizable lysine and methionine levels on the performance of lactating dairy cows: A systematic review of the literature. Livest. Sci. 2-3:115126.

Roffler, R. E., J. E. Wray, and L. D. Satter. 1986. Production responses in early lactation to additions of soybean meal to diets containing predominantly corn silage. J. Dairy Sci. 69:1055-1062.

Safayi, S., and M. O. Nielsen. 2013. Intravenous supplementation of acetate, glucose or essential amino acids to an energy and protein deficient diet in lactating dairy goats: Effects on milk production and mammary nutrient extraction. Small Rumin. Res. 112:162173.

Schoorl, N. 1929. Suiker-titratie (Sugar titration). Chem. Weekbl. $26: 130-134$

Sjaunja, L. O., L. Baevre, L. Junkkarinen, J. Pedersen, and J. Setala. 1991. A Nordic proposal for an energy corrected milk (ECM) formula. Performance recording of animals: State of the art 1990. Pages 156-157 in EAAP Publication 50. EAAP, Rome, Italy.

Smith, N. E., F. R. Ufford, C. E. Coppock, and W. G. Merrill. 1978 One group versus two group systems for lactating cows fed complete rations. J. Dairy Sci. 61:1138-1145.

Stoldt, W. 1952. Vorschlag zur Vereinheitlichung der Fettbestimmung in Lebensmitteln (Suggestion to standardize the determination of fat content in foods). Fette und Seifen 54:206-207.

Sutton, J. D. 1989. Altering milk composition by feeding. J. Dairy Sci. 72:2801-2814.

Tilley, J. M. A., and R. A. Terry. 1963. A two-stage technique for the in vitro digestion of forage crops. J. Br. Grassl. Soc. 18:104-111.

Veerkamp, R. F., G. Simm, and J. D. Oldham. 1994. Effects of interaction between genotype and feeding system on milk production, feed intake, efficiency and body tissue mobilization in dairy cows. Livest. Prod. Sci. 39:229-241.

Volden, H. 2011. NorFor-The Nordic Feed Evaluation System. H. Volden, ed. EAAP Publication No. 130. Wageningen Academic Publishers, Wageningen, the Netherlands.

Walker, N. D., C. J. Newbold, and R. J. Wallace. 2005. Nitrogen metabolism in the rumen. Pages 71-115 in Nitrogen and Phosphorus Nutrition of Cattle: Reducing the Environmental Impact of Cattle Operations. E. Pfeffer and A. Hristov, ed. CABI Publishing, Wallingford, UK.

Weisbjerg, M. R., and T. Hvelplund. 1993. Estimation of net energy content (FU) in feeds for cattle. Report No. 3/993. National Institute of Animal Science, Frederiksberg Bogtrykkeri, Copenhagen, Denmark.

Weisbjerg, M. R., N. B. Kristensen, T. Hvelplund, P. Lund, and P. Løvendahl. 2010. Malkekoens produktion ved reduceret kvælstoftildeling [The production of the dairy cow at reduced $\mathrm{N}$ allocation]. Pages 17-29 in Malkekoens biologiske potentiale for reduceret udskillelse af fosfor, kvælstof og metan [The biological potential of the dairy cow to reduce emission of phosphor, nitrogen and methane]. N. B. Kristensen, ed. Intern. report. Husdyrbrug nr. 22, maj 2010. Det Jordbrugsvidenskabelige Fakultet, Aarhus Universitet.

Weisbjerg, M. R., N. B. Kristensen, T. Hvelplund, P. Lund, and P. Løvendahl. 2012. Feed intake and milk yield responses to reduced protein supply. Page 113 in Book of Abstracts, EAAP Conf. 2012. Wageningen Academic Publishers, Wageningen, the Netherlands. 